DOI: 10.15393/j9.art.2019.6342

УДК 821.161.1.09“18”

Борис Николаевич Тихомиров

(Санкт-Петербург, Российская Федераиия)

btikhomirov@rambler.ru

\title{
Стихотворное «Послание Белинского к Достоевскому»: итоги и проблемы изучения
}

Аннотация. Статья посвящена комплексному рассмотрению проблем изучения стихотворного «Послания Белинского к Достоевскому» («Витязь горестной фигуры...») - пародийного текста, дошедшего до нашего времени лишь в списках разной степени авторитетности и без твердого указания его авторов. В статье обобщены и критически проанализированы существовавшие прежде исследовательские подходы к проблемам источников, авторства и датировки стихотворения. Подтверждено новыми наблюдениями высказанное ранее В. Н. Захаровым предположение об участии в создании этого коллективного произведения, наряду с Тургеневым и Некрасовым, Ивана Панаева. На основе анализа архитектоники «Послания...» выдвинута мотивированная гипотеза о двух редакциях этого текста - ранней, краткой и окончательной, пространной. Осуществлена реконструкция краткой редакции, более строго соответствовавшей жанровой природе «Послания...». В свете выдвинутой гипотезы об истории текста произведения уточнены подходы к решению проблемы его датировки. По ходу изложения прокомментированы некоторые содержательные элементы текста, дающие дополнительную информацию для решения означенных проблем.

Ключевые слова: Достоевский, Белинский, Некрасов, Тургенев, Панаев, альманах «Левиафан», пародия, история текста, проблемы авторства и датировки, архитектоника, смысловой и ритмический сбои, иерархическая повествовательная дистанция, гипотетическая реконструкция

Об авторе: Тихомиров Борис Николаевич - доктор филологических наук, заместитель директора по научной работе, Литературно-мемориальный музей Ф. М. Достоевского в Санкт-Петербурге (191002, Российская Федерация, г. Санкт-Петербург, Кузнечный пер. 5/2)

Дата поступления: 14.04 .2019

Дата публикации: 09.09.2019

Для цитирования: Тихомиров Б. Н. Стихотворное «Послание Белинского к Достоевскому»: итоги и проблемы изучения // Проблемы исторической поэтики. - 2019. - Т. 17. - № 3. - C. 62-85. DOI: 10.15393/j9. art.2019.6342

(C) Б. Н. Тихомиров, 2019 
$\mathrm{B}$ своей давней, богатой ценными наблюдениями статье «По В поводу одного мифа о Достоевском» ${ }^{1}$ В. Н. Захаров всесторонне рассмотрел историю возникновения и бытования известной сплетни, получившей распространение в литературной среде. Главный пункт сплетни заключался в том, что юный, только что вступивший на писательское поприще автор романа «Бедные люди», вследствие вскружившего ему голову чрезвычайного успеха первого произведения, якобы потребовал от издателя, чтобы в печати его новое творение, для отличия от текстов других авторов, было отмечено какимнибудь выразительным типографским способом, например чтобы каждая страница была обведена особой каймою или бордюром. Обобщив обширный и разнообразный историколитературный материал, впервые собранный в единую картину, исследователь убедительно доказал, что названная сплетня не имеет под собой никаких серьезных фактических оснований, что это не более чем «биографический миф литературного происхождения» [Захаров: 118]. Анализируя истоки возникновения «анекдотика с каймой» ${ }^{2}$ В. Н. Захаров значительное внимание уделил, в частности, пародийному стихотворному «Посланию Белинского к Достоевскому» («Витязь горестной фигуры...»), финальные строки которого: «Буду нянчиться с тобою, / Поступлю я как подлец, / Обведу тебя каймою, / Помещу тебя в конец» - и явились, по его мнению, первоначалом рассматриваемой сплетни. Ученый подверг критическому рассмотрению разночтения, имевшие место в публикациях как отдельных фрагментов, так и полного текста «Послания...»; поставил и по-новому решил проблему авторства этого стихотворения; уделил внимание вопросу его датировки и проч. Разностороннее освещение различных аспектов изучения стихотворного «Послания Белинского к Достоевскому», осуществленное В. Н. Захаровым, бесспорно, является на сегодняшний день наиболее основательным и полным в отечественной науке.

Тем не менее нужно признать, что, поскольку В. Н. Захарова прежде всего интересовали генезис и формы бытования «анекдотика с каймой», далеко не все проблемы, встающие при комплексном рассмотрении «Послания...», получили в его 
статье одинаково подробную проработку: некоторые из наблюдений и соображений исследователя допускают дальнейшие развитие и уточнение, другие требуют полемической корректировки.

Так, вполне соглашаясь с В. Н. Захаровым в общем решении проблемы авторства «Послания...», я существенно по-другому склонен представлять историю текста этого сатирического стихотворения. Но прежде чем коснуться данного аспекта, необходимо сделать небольшой экскурс в проблему авторства.

После первой полной публикации текста «Послания...», напечатанного в 1892 г. М. П. Драгомановым в приложении к изданию «Писем К. Дм. Кавелина и Ив. С. Тургенева к Ал. Ив. Герцену»³, в научной литературе укрепилось мнение, что соавторами этого сатирического произведения являются Н. А. Некрасов и И. С. Тургенев. В частности, такая точка зрения принята публикаторами «Послания...» и в двух последних академических Полных собраниях сочинений и писем названных авторов, где текст стихотворения публикуется в разделе «Коллективное» ${ }^{4}$ В. Н. Захаров аргументированно корректирует такую атрибуцию, называя третьего соавтора И. И. Панаева. Тут, однако, сохраняется некоторая неясность, требующая уточнения.

В преамбуле к публикации Драгоманов вполне определенно сообщает, что публикует «Послание...» по «копии стихотворения», найденной им «в бумагах А. И. Герцена» ${ }^{5}$. Важная деталь: в трех случаях в списке, публикуемом Драгомановым, была сделана правка, оговоренная в затекстовом примечании 6 . Происхождение этой копии (в том числе - чьей рукой она сделана $\left.{ }^{7}\right)$, путь ее попадания в архив Герцена остаются неизвестными, так же как и ее сегодняшнее местонахождение. В 1903 г. этот же текст был тождественно воспроизведен ${ }^{8}$ в «Литературном вестнике» по копии, которая была доставлена в редакцию В. П. Батуринским. В преамбуле указано, что «копия этого стихотворения» основана «на списке, который хранится среди бумаг А. И. Герцена». Новацией данной публикации явилось подстрочное примечание, принадлежащее, очевидно, Батуринскому ${ }^{10}$, в котором указывается, что «поправки по рукописи Некрасова сделаны рукой Тургенева» ${ }^{11}$. 
Публикация в «Литературном вестнике» содержит вопиющее противоречие, которое еще не было отмечено прежде. Драгоманов, получивший от А. А. Герцена материалы из архива отца для подготовки их к печати, пишет о «копии стихотворения». В преамбуле к публикации в «Литературном вестнике» редакция также сообщает, что к ним поступила «копия $\langle\ldots$. , основанная на списке, который хранится среди бумаг А. И. Герцена», то есть что в журнал как будто была предоставлена копия $c$ копии. И в то же время из приведенного выше подстрочного примечания как будто следует, что в распоряжении публикатора находился автограф стихотворения, написанный рукой Некрасова с правкой рукой Тургенева $a^{12}$. Как разрешить это противоречие?

С одной стороны, можно было бы предположить, что Драгоманов при подготовке публикации ошибочно принял $a 8_{-}$ тограф Некрасова с правкой Тургенева за список («копию»), даже не разглядев и не отметив, что правка внесена другой рукой, а Батуринский оказался более опытным текстологом и сделал аутентичную атрибуцию текста ${ }^{13}$. Но ведь и редакция «Литературного вестника» сообщает о «копии <...> основанной на списке [sic!], который хранится среди бумаг А. И. Герцена». Так что вопросы всё равно остаются. И главный из них: каким образом Батуринскому могла быть доступна публикуемая рукопись стихотворения?

Дело в том, что после публикации 1892 г. материалы из герценовского архива в значительной части остались в распоряжении Драгоманова, политического эмигранта, проживавшего с конца 1880-х гг. в Болгарии. В 1895 г. он умер, и весь его обширный архив хранился в Софии, у его дочери, Л. М. Драгомановой-Шишмановой (1866-1937) ${ }^{14}$. Представляется маловероятным, что Батуринскому могла быть известна судьба означенной части архива Герцена и что он имел доступ к этим материалам. В частности, показательно, что в публикации «Литературного вестника» нет упоминаний о софийском архиве Драгоманова и лишь сообщается о «списке, который хранится среди бумаг А. И. Герцена». А из этого в свою очередь можно заключить, что, скорее всего, Батуринский предоставил редакции журнала стихотворение, скопированное из женевской публикации Драгоманова ${ }^{15}$, и указание на то, что основной 
текст записан рукой Некрасова, а правка внесена Тургеневым, - не более чем домысел публикатора ${ }^{16}$.

Приведенные соображения имеют гипотетический характер, но крайне важны для дальнейшего изложения. В. Н. Захаров доверился публикации "Литературного вестника», принял за непреложный факт «графологическую характеристику рукописи» [Захаров: 116], приведенную в примечании Батуринского, приложил немалые усилия, чтобы доказать, что «то, что текст послания написан рукой Некрасова с исправлениями Тургенева, еще не говорит о том, что круг авторов послания ограничен ими» [Захаров: 116]. Сказанное бесспорно, но есть одно «но». И у Драгоманова, и у Батуринского в обеих публикациях текст рукописи завершается датой - «1846» и именами авторов - «Тургенев и Некрасов». Если перед нами список, то указание на авторов, естественно, имеет относительный характер, если же - автограф рукой Некрасова, то это уже абсолютное свидетельство о двух авторах «Послания...» (только двух). И никакие косвенные наблюдения, дающие основания ставить вопрос о соавторстве Панаева, поколебать его будут уже не в силах. Вот почему так важно было заострить внимание на сомнительности «графологической характеристики рукописи», данной в публикации «Литературного вестника». А приводимые ниже новые наблюдения в пользу соавторства Панаева, в свою очередь, будут дополнительным косвенным аргументом против текстологического свидетельства Батуринского.

Какие же аргументы в пользу соавторства Панаева приводит В. Н. Захаров? Во-первых, он отмечает прямое указание М. М. Стасюлевича, сообщившего в 1880 г. в редакционной заметке «Вестника Европы», что «Некрасов, Панаев и др. придумали написать от имени Белинского стихотворное послание к автору “Бедных людей”, которое заключалось таким четверостишием:

Будешь ты доволен мною;

Поступлю я, как п<одлец>...

Обведу тебя каймою,

Помещу тебя в конец» ${ }^{17}$.

Скрупулезно восстановив контекст полемики в печати, развернувшейся вокруг «анекдотика с каймой», обнародованного 
в воспоминаниях П. В. Анненкова, В. Н. Захаров доказательно установил, что при подготовке этой заметки Стасюлевич пользовался консультациями находившегося в это время в Петербурге И. С. Тургенева. Таким образом, указание на соавторство Панаева исходило от одного из бесспорных авторов - Тургенева. «В пристойном светском тоне названы умершие авторы, остальные скрыты в сокращении “др."”, заключает исследователь [Захаров: 116]. Действительно, Панаева и Некрасова уже не было в живых, а давать новый публичный повод для ссоры Достоевского с Тургеневым было нежелательно, почему и потребовалось это «др.».

Отметил В. Н. Захаров и формулировку И. С. Тургенева, сохраненную в дневнике А. Н. Луканиной: «После мы все вместе сочинили по этому поводу шуточные стихи, описывавшие похождения молодого автора, - припев был такой: “Обнесу тебя каймою, помещу тебя в конец”» [Луканина: 221]. «...Мы все вместе» - это заведомо больше, чем двое: как минимум - трое.

С другой стороны, исследователь детально проанализировал архитектонику 32-строчного стихотворения и выявил лексико-стилистическую и ритмическую разнородность его частей. «В композиции “послания”, - пишет В. Н. Захаров, четко обозначены три части: первые десять стихов с насмешками над неожиданной литературной славой “юного литератора”, второй десяток стихов с эпизодом об обмороке во время его светских похождений и три заключительных четверостишия с предложением Белинского Достоевскому» [3ахаров: 116]. Дополнительно сославшись на воспоминания Я. П. Полонского, который прочитанные ему Тургеневым первые восемь строк «Послания...» воспринял как завершенную эпиграмму на Достоевского, единолично сочиненную его собеседником $^{18}$, а также, напомнив, что именно Панаев дважды в фельетонах «Современника» (в 1847 и 1855 гг.) издевательски излагал обстоятельства конфуза, случившегося с Достоевским в салоне графа В. А. Соллогуба в доме Виельгорских, в то время как ни Некрасов, ни Тургенев ни разу не упоминали об этом инциденте, - В. Н. Захаров приходит к заключению: первая часть стихотворения принадлежит Тургеневу, вторая 
написана Панаевым, автором третьей является Некрасов. «Конечно, “послание” - коллективное произведение, так что не исключены и иные формы соавторства каждого в любой из частей, но каждая часть имеет своего основного автора», уточняет свой вывод исследователь [Захаров: 117].

До сих пор я был в принципе солидарен с В. Н. Захаровым; далее начинаются разногласия. Исследователь представляет коллективный творческий процесс трех соавторов, так сказать, линейно: Тургенев сочиняет тематически единые первые десять строк (две с половиной строфы) - саркастически-гиперболическое прославление «милого пыща» Достоевского, затем следующие десять строк (еще две с половиной строфы) приписывает Панаев, предложивший свой сюжетный поворот, глумливый рассказ об обмороке, в который автор «Бедных людей» на "рауте светском» упал от волнения перед светской красавицей; финальную часть (последние три строфы), наиболее соответствующую жанру послания, довершает Некрасов.

Однако анализ художественной структуры стихотворения, смыслового развертывания его внутреннего «сюжета» позволяет представить логику творческого процесса существенно иначе. В архитектонике «Послания...» обнаруживаются два плохо стыкующихся (и семантически, и ритмически) пласта, что позволяет выдвинуть гипотезу о двух разнесенных во времени этапах творческой работы соавторов над текстом произведения, иначе говоря - о двух редакциях стихотворения: ранней, краткой и окончательной, пространной. Для наглядной демонстрации выдвинутого предположения позволю себе прибегнуть к инверсированному изложению и, забегая вперед, сразу же представлю гипотетически реконструируемую первоначальную, краткую 20-стишную редакцию:

ПОСЛАНИЕ БЕЛИНСКОГО К ДОСТОЕВСКОМУ

Витязь горестной фигуры, Достоевский, милый пыщ,

На носу литературы

Рдеешь ты как новый прыщ.

Хоть ты юный литератор,

Но в восторг уж всех поверг:

Тебя знает Император,

Уважает Лейхтенберг. 
С высоты такой завидной,

Слух к мольбе моей склоня,

Брось свой взор пепеловидный,

Брось, великий, на меня!

Ради будущих хвалений

(Крайность, видишь, велика)

Из неизданных творений

Удели не «Двойника».

Буду нянчиться с тобою,

Поступлю я как подлец,

Обведу тебя каймою,

Помещу тебя в конец.

В академическом собрании Тургенева название стихотворения и в основном корпусе, и в примечаниях, и в оглавлении немотивированно напечатано в ломаных скобках, то есть представлено как неавторское, редакционное ${ }^{19}$. Однако если за основу взят список «из бумаг А. И. Герцена» ${ }^{20}$, то это не так: и в публикации Драгоманова, и в публикации Батуринского стихотворный текст тождественно озаглавлен: «Послание Белинского к Достоевскому». И это крайне важно, так как первоначальная редакция строго соответствовала данному названию - и по жанру, и по смысловому наполнению стихотворения.

Уже в XIX в. и мемуаристы, и первые публикаторы и комментаторы как фрагментов, так и полного текста «Послания...» раскрывали в общих чертах историко-литературную ситуацию, применительно к которой было написано это сатирическое стихотворение. Наиболее подробно ее восстановил В. Н. Захаров. В самом конце 1845 г. Белинский принял решение окончательно порвать с А. А. Краевским и уйти из «Отечественных записок». Но он всегда брал у Краевского деньги вперед, был у издателя в кабале и, уходя, тем более «в никуда», оказывался в полном безденежье. Чтобы как-то смягчить ситуацию, Белинский, имея в виду в том числе и финансовый успех недавних изданий Н. А. Некрасова - двух выпусков «Физиологии Петербурга», решил выпустить к Пасхе 1846 г. «толстый, огромный альманах» ${ }^{21}$ «Левиафан». Успех альманаха - 
понятно - зависел от привлеченных литературных сил. И начиная с Рождества 1845 г. Белинский стал вербовать авторов в свое издание (известно, например, его письмо к Герцену от 2 января 1846 г., содержащее приглашение принять участие в «Левиафане»). Естественно, как одну из ключевых фигур, он пригласил в альманах и Достоевского - автора еще не напечатанных, но уже произведших фурор в литературных кругах «Бедных людей», о согласии которого, кстати, упоминает в указанном письме к Герцену («Достоевский дает повесть» ${ }^{22}$ ). Скорее всего, общаясь с ним в это время чуть не ежедневно, Белинский обратился к Достоевскому напрямую, то есть в устной форме. Но в сатирическом стихотворении его обращение предстает как письменное «послание».

В историко-литературном контексте, который я кратко очертил, не может не броситься в глаза, что в гипотетически реконструируемой краткой редакции практически каждое слово работает на раскрытие означенной «фабульной ситуации» стихотворения. Белинский - автор «послания» - находится в критическом положении и жизненно заинтересован («крайность, видишь, велика») в участии Достоевского в альманахе. Соблазняя желанного автора обещанием «будущих хвалений», гарантируя ему со стороны издателя всевозможные преференции («буду нянчиться с тобою»), он славословит Достоевского, поет ему дифирамбы (конечно же, по законам жанра сатирического произведения иронически утрированные). Одним из элементов поэтики рассматриваемого стихотворного текста является иерархическая повествовательная дистанция, с которой, вознеся «великого» Достоевского на «завидную» - для него, критика Белинского! - «высоту», издатель «Левиафана» - снизу вверх — «с мольбой» обращается к адресату своего «Послания...». Вот на этом обстоятельстве необходимо немного задержаться.

Третья строфа в моем 20-стишном варианте начинается словами: «С высоты такой завидной / Слух к мольбе моей склоня...». О какой «завидной высоте» тут идет речь? Ответ содержится в непосредственно предшествующей этим строчкам второй строфе: «Хоть ты юный литератор, / Но в восторг уж всех поверг: / Тебя знает Император, / Уважает Лейхтенберг». 
И далее: «С высоты такой завидной...» и т. д. Очень ясная, четкая, как это называют кинематографисты, «склейка».

А вот теперь, после сказанного, обратимся к «каноническому» тексту «Послания...»:

Хоть ты юный литератор,

Но в восторг уж всех поверг:

Тебя знает Император,

Уважает Лейхтенберг,

За тобой Султан турецкий

Скоро вышлет визирей.

Но когда на раут светский

Перед сонмище князей,

Ставши мифом и вопросом,

Пал чухонскою звездой

И моргнул курносым носом

Перед русой красотой,

Как трагически недвижно

Ты смотрел на сей предмет

И чуть-чуть скоропостижно

Не погиб во цвете лет.

С высоты такой завидной,

Слух к мольбе моей склоня,

Брось свой взор пепеловидный,

Брось, великий, на меня!..

Дальше идут еще две строфы, но можно уже остановиться. И, вновь обратившись к строке «С высоты такой завидной...», повторить вопрос: о какой «завидной высоте» тут идет речь? То, что было вполне ясным, естественным, логичным в первом варианте, превращается едва ли не в бессмыслицу в «каноническом» тексте: «Как трагически недвижно / Ты смотрел на сей предмет / И чуть-чуть скоропостижно / Не погиб во цвете лет...» - «С высоты такой завидной...» [???]. Действительно бессмыслица! Особенно если учесть известный комментарий к этим строкам Д. В. Григоровича: «С Достоевским, представленным на вечере у Виельгорских красавице г-же 
Сенявиной, сделалось от волнения дурно» ${ }^{23}$. Из других источников мы знаем, что он упал в обморок, его унесли в другую комнату, где приводили в чувство одеколонами и т. д. ${ }^{24}$ И после всего этого: «С высоты такой завидной...». Налицо явный смысловой сбой.

Представленный выше 20-строчный вариант был исключительно цельным, подчиненным единой художественной телеологии, стройным и логичным по своему внутреннему движению. На его фоне эпизод на «рауте светском» воспринимается как нечто инородное, неорганичное для предшествующего и последующего текста, нарушающее внутренние установки пусть и пародийного послания издателя к автору, в котором он заинтересован. Это вполне «автономная» по своему содержанию эпиграмма внутри построенного на других принципах стихотворения. Тут даже другого качества юмор, переходящий в едкий сарказм и открытое глумление, отличный от мягкого юмора первых строк ${ }^{25}$. Если же в придачу учесть, что на границах эпизода на "рауте светском» присутствуют заметные сбои: уже отмеченный смысловой на нижней границе и резкий ритмический - на верхней (так называемый межстрофный анжамбеман: «За тобой Султан турецкий / Скоро вышлет визирей. / Но когда на раут светский / Перед сонмище князей, // Ставши мифом и вопросом, / Пал чухонскою звездой...»), - то естественно приходит предположение, что весь этот эпизод - не что иное, как позднейшая вставка.

Из трех предполагаемых авторов «Послания...», по-видимому, только Панаев был очевидцем обморока Достоевского на «рауте светском»: в проспекте его «Воспоминаний», которые печатались в 1862 г. в «Современнике», обозначен эпизод: «Достоевский в салоне Соллогуба» $»^{26}$. Однако, к сожалению, скоропостижная смерть Панаева прервала его работу над мемуарами именно на этом месте и эпизод, увы, не был им рассказан. Заслуживает внимания также, что в фельетоне 1847 г., где Панаев впервые касается этого инцидента в прозаической форме, он почти буквально цитирует (с изменением лица) строчку из стихотворного «Послания... »: «Я, признаюсь, сильно струсил, когда появился в многочисленной и незнакомой 
толпе, струсил и чуть-чуть скоропостижно не лишился жизни; но меня увели в другую комнату и похвалами моему великому таланту привели в чувство...» [Панаев, 1847: 154] ${ }^{27}$. Эти наблюдения дополнительно подкрепляют мнение В. Н. Захарова о том, что автором стихотворного эпизода на «рауте светском» должен был быть Панаев, который, однако, в логике приведенных наблюдений, сочинил свой пассаж уже тогда, когда тургеневско-некрасовская ранняя редакция «Послания...» была написана, и включил его в завершенный текст стихотворения, нарушив тем его художественную стройность и жанровое единство.

Такая интерпретация истории текста «Послания...» заставляет также передвинуть границу, разделяющую тургеневскую и панаевскую части стихотворения. По заключению В. Н. Захарова, Тургенев закончил свою часть в середине mретьей строфьы: «Хоть ты юный литератор, / Но в восторг уж всех поверг: / Тебя знает Император, / Уважает Лейхтенберг, // За тобой Султан турецкий / Скоро вышлет визирей» (то есть санитаров: ядовитый намек на Поприщина из гоголевских «Записок сумасшедшего», который, как помним, возомнив себя испанским королем, ждал депутатов из Испании и удивлялся, что они так долго не едут). И с середины же третьей строфы, по версии исследователя, продолжил свою часть Панаев: «Но когда на раут светский / Перед сонмище князей...». Такое распределение авторства, повторю, предполагает линейную последовательность творческого процесса, что мне представляется маловероятным. В логике же позднейшей вставки и содержащее отмеченную гоголевскую аллюзию двустишие: «За тобой Султан турецкий / Скоро вышлет визирей» - это тоже панаевское творение (а не «повисшие» строчки Тургенева), своеобразный «мостик», который Панаев перебрасывает к своему эпизоду на «рауте светском» от концовки тургеневского 8-стишия: «Тебя знает Император, / Уважает Лейхтенберг».

Таким образом, если в истолковании В. Н. Захарова авторство Тургенева, Панаева и Некрасова распределяется в последовательности текста по схеме «10-10-12», то в свете моей гипотезы - «8-12-12». Причем срединные двенадцать строк 
(три полных строфы) - это позднейшая панаевская вставка. И если принять предложенную гипотезу, то - хотя бы в примечаниях - 20-стишное стихотворение Некрасова и Тургенева надо печатать как самостоятельную, раннюю редакиию «Послания Белинского к Достоевскому». Мне представляется, что она того заслуживает. Сам по себе - в силу своей осязательной цельности, стройности, органично-естественного движения стиха - 20-строчный вариант является еще одним - эстетическим! - аргументом в пользу выдвинутой гипотезы.

Приведенная интерпретация истории текста «Послания...» позволяет также вернуться к проблеме датировки стихотворения. В исследовательской литературе и комментариях к публикациям высказывались различные мнения по этому вопросу. Так, отталкиваясь от строк предпоследней строфы: «Из неизданных творений / Удели не “Двойника”», комментаторы академического собрания Тургенева заключают: «Так как “Двойник” появился во второй (февральской) книжке “Отечественных записок” за 1846 год, послание могло быть написано лишь в самом начале января этого года ${ }^{28}$. Однако такое решение создает ряд трудноразрешимых проблем. «Петербургский сборник» с романом «Бедные люди» вышел в свет не ранее середины января 1846 г. Даже при условии, что это саркастическая гипербола, невозможно представить, чтобы строки: «Хоть ты юный литератор, / Но в восторг уж всех поверг: / Тебя знает Император, / Уважает Лейхтенберг ${ }^{29}-$ были написаны до обнародования первого произведения Достоевского. Так что датировку «самым началом января» 1846 г. надо категорически исключить.

Комментаторы академического собрания Некрасова более осторожно пишут, что «стихотворение, очевидно, следует отнести к январю 1846 г.» ${ }^{30}$. Такая датировка гораздо корректнее, однако вопросы всё равно остаются. Наряду с всеобщим «восторгом» литературная репутация Достоевского характеризуется в стихотворении в словах: «Ставши мифом и вопросом...». Как представляется, это в большей степени, чем ситуации после триумфа «Бедных людей», соответствует времени, когда публикации сначала «Двойника», а затем 
«Господина Прохарчина» (октябрь 1846 г.) заставили В. Г. Белинского и его кружок усомниться, не поторопились ли они, провозгласив Достоевского «новым Гоголем». В этой связи стоит указать, что в академическом собрании Достоевского комментаторы допускают гораздо более широкую датировку. Называя «Послание...» «эпиграммой», они пишут: «...не исключено, однако, что она относится к лету или даже осени того же (1846-го. - Б. Т.) года ${ }^{31}$.

Но как же быть с «неизданным» «Двойником»? Выше уже было отмечено, что «Послание Белинского к Достоевскому» пародирует реальные послания, с которыми критик обращался к друзьям-литераторам в конце декабря 1845 г. - начале января 1846 г., когда затевал издание альманаха «Левиафан». В это время работа Достоевского над «Двойником» еще не была завершена. И в точном соответствии с реалиями изображаемой историко-литературной ситуации авторы «Послания...» именуют вторую повесть автора «Бедных людей» «неизданным творением». Однако это вполне могло быть написано и ретроспективно. Более того, выразившееся в рассматриваемых строках скептическое отношение Белинского к «Двойнику» с полной определенностью проявилось уже после опубликования повести ${ }^{32}$. Именно так рассуждает и В. Н. Захаров. «Если придать фразе "Из неизданных творений удели не «Двойника»" прямое значение, - пишет исследователь, - то совпадают хронология текста “послания" и литературная история несостоявшегося альманаха Белинского. Но возможно и переносное значение фразы. В таком случае “удели не «Двойника»" можно рассматривать как эстетическую оценку повести, вызвавшей противоречивые толки» [Захаров: 118].

Не менее значим для решения проблемы датировки «Послания...» вопрос о конфузе, случившемся с Достоевским на «рауте светском». Выше уже был приведен комментарий к данному эпизоду Д. В. Григоровича: «С Достоевским, представленным на вечере у Виельгорских красавице г-же Сенявиной, сделалось от волнения дурно». Этот инцидент произошел с писателем в салоне графа В. А. Соллогуба, который жил в доме своего тестя Мих. Ю. Виельгорского. В своих мемуарах 
Соллогуб рассказывает, что познакомился с Достоевским сразу же по прочтении его романа «Бедные люди». Сообщив о своем посещении писателя, которого «нашел в маленькой квартире на одной из отдаленных петербургских улиц», мемуарист пишет, что в завершение своего визита он пригласил Достоевского поехать к нему «запросто пообедать». Тот сконфузился и отказался под тем предлогом, что «в большом свете отроду не бывал». Соллогуб уговаривал его, но безуспешно. «Достоевский <...> остался непреклонным, - сообщает он, - и только месяца два спустя решился однажды появиться в моем зверинце» ${ }^{33}$ (так мемуарист именует особую гостиную в своей квартире, расположенную за его кабинетом, в которой он принимал самую «разношерстную» публику).

В конце жизни В. А. Соллогуб смутно помнил детали этого события: он сообщает, что прочитал «Бедных людей» в «одном из тогдашних ежемесячных изданий», называет издателем журнала, где был напечатан роман Достоевского, А. А. Краевского и т. п. ${ }^{34}$ Тем не менее из его мемуаров следует, что он читал «Бедных людей» в печатном виде, а не по рукописи или в корректуре, как с ним знакомились еще в конце 1845 г. некоторые литераторы из окружения Белинского. И, следовательно, его личная встреча с писателем произошла не ранее второй половины января, когда вышел в свет «Петербургский сборник», а посещение Достоевским «зверинца» Соллогуба, где с ним случился уже не однажды упомянутый конфуз, - не ранее конца марта 1846 г. Но если так, то и стихотворные строки, в которых преломилось данное событие, не могли быть написаны ранее этого времени. «Что ж, - резюмирует И. Л. Волгин, приведя эти хронологические выкладки. - Теперь, пожалуй, можно по-новому, датировать плод коллективных досугов - “Послание Белинского к Достоевскому": не ранее апреля 1846 года» [Волгин: 410]

К этому можно было бы добавить: и не позднее. 26 апреля 1846 г. Некрасов на несколько месяцев уехал из Петербурга. 5 мая и Тургенев отправился сначала в Москву, а затем на всё лето и часть осени в деревню; вернулся он в Северную столицу лишь 17 октября 1846 г. $^{36}$ К этому времени проект издания «Левиафана» был уже окончательно «похоронен», и сочинение 
«Послания Белинского к Достоевскому» спустя почти год после события, положенного в основу стихотворения, представляется совершенно нереальным.

Что ж, проблема датировки решена? Увы, нет. Концом марта - апрелем 1846 г. датировать создание «Послания...» можно было бы лишь в том случае, если бы в основу соображений И. Л. Волгина не были положены наблюдения над теми элементами стихотворного текста, которые выше рассматривались как позднейшая вставка. Да, три строфы, сочиненные Панаевым, судя по всему, действительно не могли быть написаны раньше конца марта - начала апреля 1846 г. Больше того, похоже, что конфуз с Достоевским, давший новый материал для ядовитой эпиграммы, и обусловил включение трех дополнительных панаевских строф в уже написанное «Послание...» Тургенева и Некрасова. Но именно поэтому хронология «соллогубовского сюжета» биографии Достоевского не может быть положена в основу датировки исходной, краткой редакции «Послания Белинского к Достоевскому». 20-строчное тургеневско-некрасовское стихотворение, скорее всего, могло быть написано во второй половине января - феврале или даже марте 1846 г. Панаевская же вставка в принципе допускает гораздо более широкую датировку. Показательно, кстати, что в фельетонной форме Панаев обращался к инциденту в «зверинце» Соллогуба и в 1847, и в 1855 гг.

Вот как выглядит под его пером этот эпизод в прозаическом изложении: «Одна барышня с пушистыми пуклями и с блестящим именем, белокурая и стройная, пожелала его видеть, наслышавшись о нем $<\ldots>$ и наш кумирчик был поднесен к ней $<\ldots .>$. Барышня с пушистыми локонами изящно пошевелила своими маленькими губками $<\ldots .>$ и хотела отпустить нашему кумирчику прелестный комплимент <...> как вдруг он побледнел и зашатался. Его вынесли в заднюю комнату и облили одеколоном. Он очнулся, но уже не входил в салон, где сидела барышня с пушистыми локонами...» [Панаев, 1855: 238-239].

Тут присутствует и еще одна проблема, касающаяся, впрочем, больше биографии Достоевского, нежели творческой истории «Послания...». Из комментария Григоровича известна фамилия героини этого эпизода - Сенявина. И. Л. Волгин 
предположил, что имеется в виду Александра Васильевна Сенявина (урожд. Гоггер, 1803-1862) - жена товарища (заместителя) министра внутренних дел, сенатора, тайного советника Ивана Сенявина [Волгин: 401-403] ${ }^{37}$. Однако сомнительно, чтобы А. В. Сенявина, дама за сорок лет, могла претендовать на эффектную роль «барышни с пушистыми локонами» из фельетона Панаева. Тут необходимо искать других кандидатов.

В 1859 г., когда Достоевский несколько месяцев после возвращения из Сибири прожил в Твери, он пользовался покровительством местного губернатора графа П. Т. Баранова. Жена губернатора оказалась его старинной знакомой, с которой он встречался... как раз в доме Виельгорских в 1846 г. Вот как он сообщает об этом в письме своему товарищу барону А. Е. Врангелю: «Я здесь сделал знакомство, между прочим с графом Барановым (губернатором). Графиня прекрасная женщина (Васильчикова урожденная), которую я встречал еще девушкой в Петербурге, у их родственника Соллогуба, о чем она мне сама первая напомнила» ${ }^{38}$. Анна Алексеевна Баранова (урожд. Васильчикова, 1823 или 1827-1890), действительно, была двоюродной сестрой графа Соллогуба по материнской линии. А вот по отцовской линии у нее был также двоюродный брат - Александр Илларионович Васильчиков, один из секундантов на дуэли Лермонтова и Мартынова, который был женат на... Евгении Ивановне Сенявиной - дочери упомянутого выше сенатора.

Правда, в 1846 г. барышне Сенявиной было всего лишь семнадцать лет. Женой Васильчикова она станет несколько позднее. Но не вызывает сомнения, что и до свадьбы она входила в родственный круг князей Васильчиковых - родственников Соллогубов. Так что, скорее всего, именно она и является той «русой красотой» «с пушистыми пуклями и маленьким ротиком», при знакомстве с которою в «зверинце» графа Соллогуба так оконфузился Достоевский. Ее портрет десять лет назад был опубликован в одном популярном издании ${ }^{39}$.

Подведем итоги. Автограф стихотворного «Послания Белинского к Достоевскому» не сохранился. Впечатление, что в основе публикации Батуринского лежал автограф рукой 
Некрасова с правкой Тургенева, обусловленное некритическим восприятием недостоверного примечания публикатора, должно быть расценено как аберрация. Более чем вероятно, что текст, напечатанный в 1903 г. в «Литературном вестнике», вторичен по отношению к публикации Драгоманова 1892 г. По мнению В. Н. Захарова, вторичным по отношению к этой публикации является и список стихотворения из записной книжки Григоровича [Захаров: 115]. Категорически утверждать этого нельзя ${ }^{40}$, но даже если у него был свой источник, список Григоровича является менее исправным, нежели список из архива Герцена, который и должен рассматриваться как первичный, основной.

Совокупность косвенных свидетельств позволяет мотивированно утверждать, что наряду с Тургеневым и Некрасовым третьим соавтором «Послания Белинского к Достоевскому» является Панаев. Однако коллективное творчество трех авторов имело сложный характер. По гипотезе, выдвинутой на основании комплексного анализа архитектоники стихотворения и ряда содержательных элементов текста, в творческой истории «Послания...» имели место две редакции - ранняя, краткая, авторами которой были только Тургенев и Некрасов, и пространная, окончательная, возникшая в результате инкорпорации в состав цельного, завершенного текста краткой редакции трех строф, написанных Панаевым. Причем эта позднейшая вставка явилась не вполне органичной по отношению к жанрово-композиционному строю первоначальной редакции.

В свете этой гипотезы по-новому должна решаться и проблема датировки «Послания...». Поскольку при описанной истории текста конфуз, случившийся с Достоевским в салоне графа Соллогуба, отразился лишь в позднейшей панаевской вставке, датирующее значение этого факта, который, по заключению биографов писателя, имел место в конце марта начале апреля 1846 г., становится относительным: раньше означенного времени не могла быть создана пространная редакция, краткую же редакцию вполне допустимо датировать второй половиной января - мартом 1846 г. 
Для окончательного решения проблем авторства и более точной датировки «Послания...», а также истории текста стихотворения необходим поиск новых источников. На сегодняшний день ответы на данные вопросы в определенной степени имеют характер мотивированных гипотез. Таковы итоги и перспективы изучения этого раннего стихотворного произведения, в котором нашли ироническое преломление черты личности и обстоятельства вхождения в литературу молодого Достоевского.

\section{Примечания}

Исследование выполнено при финансовой поддержке Российского фонда фундаментальных исследований (РФФИ), проект № 18-012-90019 Достоевский «Нерешенные вопросы научной биографии Ф. М. Достоевского: новые печатные и архивные источники».

1 См.: [Захаров].

2 Собственное выражение Достоевского, который в подготовительных материалах к «Дневнику Писателя» 1881 г. сделал ряд набросков, свидетельствующих, что он собирался полемизировать с клеветой П. В. Анненкова, содержавшейся в его мемуарах, опубликованных в № 4 «Вестника Европы» за 1880 г. (см.: Достоевский Ф. М. Полн. собр. соч.: в 30 т. Л.: Наука, 1984. Т. 27. С. 198).

3 Письма К. Дм. Кавелина и Ив. С. Тургенева к Ал. Ив. Герцену / с объяснит. примеч. М. Драгоманова. Женева: Украинская тип., 1892. С. 207-208. Эта первая публикация полного текста «Послания Белинского к Достоевскому» не учтена в обширнейшем библиографическом издании: [Белов].

4 См.: Тургенев И. С. Полн. собр. соч. и писем: в 30 т. Соч.: в 12 т. М.: Наука, 1978. Т. 1. С. 544-545, примеч.; Некрасов Н. А. Полн. собр. соч. и писем: в 15 т. Л.: Наука, 1981. Т. 1. С. 687-688, примеч.

5 Письма К. Дм. Кавелина и Ив. С. Тургенева к Ал. Ив. Герцену. С. 207. Здесь и далее полужирные выделения в цитатах принадлежат автору статьи.

6 «Во 2-м стихе вм. мильй первоначально было написано - юный, в 5-м вм. юныц - новыци, в 22-м вм. слух - взор» (Там же. С. 208).

7 Этот аспект далее будет рассмотрен подробно.

8 Единственное разночтение - многоточие в конце 10-й строки, где в публикации М. П. Драгоманова поставлена точка. Кроме того, не различаясь по существу, по-разному поданы текстологические примечания: затекстовые в издании 1892 г., подстрочные - в 1903 г.

9 Литературный вестник. 1903. Т. 5. Кн. 1. С. 13.

10 В примечаниях академического собрания И. С. Тургенева оно представлено как редакционное. 
11 Литературный вестник. 1903. Т. 5. Кн. 1. С. 14.

12 В преамбуле к примечаниям академического собрания Н. А. Некрасова текстологическое описание рукописи, по которой печатается «Послание...», выполнено чрезвычайно невнятно: с одной стороны, указано, что публикация Драгоманова сделана «по списку Герцена» (что можно понять так, будто список сделан рукой А. И. Гериена); с другой - что в «Литературном вестнике» текст стихотворения напечатан «по копии со списка Герцена». В совокупности с указанием: «Поправки по рукописи Некрасова сделаны рукой Тургенева» - складывается совершенно фантастическая картина: будто существуют две рукописи - список, сделанный рукой А. И. Герцена, и копия с этого списка, выполненная Н. А. Некрасовым с правкой И. С. Тургенева (см.: Некрасов Н. А. Полн. собр. соч. и писем. Т. 1. С. 687, примеч.).

13 Другое, еще менее вероятное объяснение: указание на руку Некрасова и правку Тургенева содержалось в самом списке, найденном среди «бумаг А. И. Герцена», и было сделано лицом, некогда скопировавшим автограф, но Драгоманов, в отличие от Батуринского, по какой-то причине не счел нужным воспроизвести это указание в своей публикации.

14 См.: От редакции // Литературное наследство. М., 1953. Т. 61: Герцен и Огарев. Кн. 1. С. 1-2; также см.: [Попов].

15 Батуринский в это время работал над монографией «А. И. Герцен, его друзья и знакомые» (СПб., 1904. Т. 1), где широко цитировал письма И. С. Тургенева к А. И. Герцену по публикации Драгоманова 1892 г. (обобщенно сославшись на нее на с. 292). Очевидно, и «Послание Белинского к Достоевскому» скопировано им из этого же источника. Поводом же к публикации в «Литературном вестнике», как сообщается в редакционной преамбуле, послужило то обстоятельство, что в 1901 г. в Ежемесячных литературных приложениях к «Ниве» (№ 11) стихотворение «Витязь горестной фигуры...» было напечатано по менее авторитетному списку из записной книжки Д. В. Григоровича. Эмигрантское малотиражное издание Драгоманова было труднодоступно в России. Этим и была обусловлена идея републикации.

16 Можно дополнительно отметить, что в записи двух первых строф «Послания...», сделанной в 1881 г. Полонским со слов Тургенева, во 2-й («Достоевский, юный пыщ») и 5-й («Хоть ты новый литератор») строчках читаются именно те варианты, которые, согласно примечанию Батуринского, в рукописи Некрасова якобы зачеркнул и переправил Тургенев (см.: Полонский Я. П. И. С. Тургенев у себя в его последний приезд на родину (Из воспоминаний) // И. С. Тургенев в воспоминаниях современников: в 2 т. М., 1969. Т. 2. С. 400).

17 От редакции. По поводу «Воспоминаний» П. В. Анненкова // Вестник Европы. 1880. Т. 3, № 5. С. 413.

18 См. примеч. 16.

19 См.: Тургенев И. С. Полн. собр. соч. и писем. Соч. Т. 1. С. 392, 544, 574.

20 См.: Там же. С. 544, примеч. 
21 Белинский В. Г. Собр. соч.: в 9 т. М., 1982. Т. 9. С. 577.

22 Там же.

23 Ежемесячные литературные приложения к «Ниве». 1901. № 11. Стлб. 394. В библиографическом указателе С. В. Белова эта публикация ошибочно помещена под 1907 г. О том, что в нее включен вариант «Послания Белинского к Достоевскому», в аннотации не сообщается [Белов: 522]. 24 См.: [Панаев, 1855: 239].

25 По поводу образности первой строфы И. Л. Волгин тонко заметил: «Пыщ - значит человек напыщенный, надутый. Однако этот подлежащий осмеянию персонаж именуется “милым”: тональность свидетельствует о том, что объект пародии всё еще находится внутри дружеского круга» [Волгин: 394].

26 Панаев И. И. Литературные воспоминания. М.: Правда, 1988. С. 307.

27 Совпадение отмечено И. Л. Волгиным (см.: [Волгин: 410]).

Тургенев И. С. Полн. собр. соч. и писем. Соч. Т. 1. С. 544, примеч.; ср.: [Летопись... Тургенева: 118].

29 В примечаниях академического собрания Тургенева сообщается: «Повесть Достоевского “Бедные люди” стала известна Николаю I и читалась при дворе, в то время как к русской литературе вообе там относились свысока» (Тургенев И. С. Полн. собр. соч. и писем. Соч. Т. 1. С. 546). Однако никаких данных, подтверждающих это указание, не существует. Скорее всего, это не более чем ироническое преувеличение авторов «Послания...» (ср. упоминание далее турецкого Султана).

30 См.: Некрасов Н. А. Полн. собр. соч. и писем. Т. 1. С. 688, примеч.

31 Достоевский Ф. М. Полн. собр. соч. Л., 1972. Т. 1. С. 497, примеч.; повторено: Достоевский Ф. М. Полн. собр. соч. и писем: в 35 т. 2-е изд., испр. и доп. СПб., 2013. Т. 1. С. 751, примеч.

32 «В январе 1846 года, до скандального провала “Двойника”, подобное издевательское стихотворение не могло быть написано», - замечает, например, Ф. И. Евнин [Евнин: 30]. «Скандальный провал» - это, конечно же, сильное преувеличение, но точка зрения исследователя показательна.

33 Соллогуб В. А. Из «Воспоминаний» // Ф. М. Достоевский в воспоминаниях современников: в 2 т. М., 1990. Т. 1. С. 223-224.

34 Там же. С. 223.

35 Еще раньше, в 1958 г., временем «около 1 апреля», впрочем, не приводя никакой аргументации, датировал создание стихотворения Ю. Г. Оксман [Оксман: 434]. С Оксманом солидаризировался в этом вопросе Ф. И. Евнин (см.: [Евнин: 30]). Такая же датировка принята в изд.: [Летопись... Некрасова: 214].

36 См.: [Летопись... Тургенева: 112].

37 Еще раньше, в середине 1930-х гг., такое же предположение высказал Г. И. Чулков, но его биография Достоевского была опубликована только в самое последнее время (см.: [Чулков: 79-80]).

38 Достоевский Ф. М. Полн. собр. соч. Т. 28. Кн. 1. С. 344. 
39 См.: [Насурдинова: 50].

40 Григорович сообщал в письме А. С. Суворину от 29 октября 1898 г., что у него «записано до 20 горьких эпиграмм его [Тургенева] работы» (Письма русских писателей к А. С. Суворину. Л., 1927. С. 42). Таким образом, список из архива Григоровича вполне мог иметь и другой источник, нежели публикация Драгоманова. К тому же он содержит иное заглавие стихотворения - «На Достоевского» - и имеет небольшие разночтения со списком из архива Герцена. Поэтому сохраняются известные основания считать текст в записной книжке Григоровича вторым, самостоятельным списком «Послания...».

\section{Список литературы}

1. Белов С. В. Ф. М. Достоевский: указатель произведений Ф. М. Достоевского и литературы о нем на русском языке, 1844-2004. - СПб.: Российская национальная библиотека, 2011. - 755 с.

2. Волгин И. Л. Родиться в России. Достоевский и современники: жизнь в документах. - М.: Книга, 1991. - 607 с.

3. Евнин Ф. И. Достоевский и Некрасов // Русская литература. - 1971. № 3. - С. 25-48.

4. Захаров В. Н. По поводу одного мифа о Достоевском // Север. - 1985. № 11. - С. 113-120.

5. Летопись жизни и творчества И. С. Тургенева: (1818-1858) / сост. Н. С. Никитина. - СПб.: Наука, 1995. - 481 с.

6. Летопись жизни и творчества Н. А. Некрасова: в 3 т. - СПб.: Наука, 2006. - T. 1: 1821-1855. - 581 с.

7. Луканина А. Н. Мое знакомство с И. С. Тургеневым (Из воспоминаний) // И. С. Тургенев в воспоминаниях современников: в 2 т. - М.: Худож. лит., 1969. - Т. 2. - С. 221-234.

8. Насурдинова Г. Не забыть мне профиль божественный... - Великий Новгород: Печатный двор «Великий Новгород», 2009. - 119 с.

9. Оксман Ю. Летопись жизни и творчества В. Г. Белинского. - М.: Худож. лит., 1958. - 643 с.

10. Панаев И. И. Еще несколько стихотворений Нового поэта // Современник. - 1847. - Т. 2. - № 4. - Отд. IV «Смесь». - С. 154-159.

11. Панаев И. И. Заметки Нового поэта о петербургской жизни // Современник. - 1855. - Т. 54. - № 12. - С. 235-268.

12. Попов А. В. Архивное наследие А. И. Герцена на родине и за рубежом // Герценовские чтения VIII: материалы науч. конф. - Киров, 2002. - С. 6-12.

13. Чулков Г. И. Жизнь Достоевского / сост., подгот. текста, коммент. и вступ. ст. О. А. Богдановой. - М.: ИМЛИ РАН, 2015. - 472 с. (Сер. «Источниковедение литературы ХХ века». - Вып. 1). 
Boris N. Tikhomirov

(Saint Petersburg, Russian Federation)

btikhomirov@rambler.ru

\section{The Poems "The Missive of Belinsky to Dostoevsky": Results and Problems of the Study}

Acknowledgments. The reported study was funded by RFBR according to the research project no. 18-012-90019 Dostoevsky.

Abstract. The article is dedicated to a comprehensive analysis of the problems of studying the poetic "The Missive of Belinsky to Dostoevsky" ("A knight of a sad character..."), that is a burlesque text hardly survived to our days in the lists of different credibility and without a definite authorship. The former research approaches to the problems of poem's sources, authorship and dating are generalized and analyzed in a critical way in the article. A hypothesis, put forward before by V. N. Zakharov, about the participation in the creation of this joint writing of Ivan Panaev along with Turgenev and Nekrasov, is confirmed. Based on the analysis of the architectonics of "The Missive..." a reasoned hypothesis about two editions of the text - an early, brief one and a final, detailed one, is presented. The article makes an attempt of reconstruction of the brief edition that complies better with a genre type of "The Missive...". In the context of the given hypothesis about the history of the text of the writing the approaches to its dating were specified. The article makes comments on some content elements of the text providing additional information for solving the given problems.

Keywords: Dostoevsky, Belinsky, Nekrasov, Turgenev, Panaev, almanac "Leviathan", parody, history of the text, authorship and dating problems, architectonics, semantic and rhythmic failures, a multilevel narrative distance, hypothetic reconstruction

About the author: Tikhomirov Boris N. - Doctor of Philology, Deputy Director of Academic Affairs, The F. M. Dostoevsky Literary-Memorial Museum in St. Petersburg (per. Kuznechnyy 5/2, Saint Petersburg, 191002, Russian Federation)

Received: April 14, 2019

Date of publication: September 9, 2019

For citation: Tikhomirov B. N. The Poems "The Missive of Belinsky to Dostoevsky": Results and Problems of the Study. In: Problemy istoricheskoy poetiki [The Problems of Historical Poetics], 2019, vol. 17, no. 3, pp. 62-85. DOI: 10.15393/j9.art.2019.6342 (In Russ.)

\section{References}

1. Belov S. V. F. M. Dostoevskiy: Ukazatel' proizvedeniy F. M. Dostoevskogo i literatury o nem na russkom yazyke, 1844-2004 [F. M. Dostoevsky. Index of F. M. Dostoevsky's Works and Writings on Him in the Russian Language, 1844-2004]. St. Petersburg, The National Library of Russia Publ., 2011. 755 p. (In Russ.) 
2. Volgin I. L. Rodit'sya v Rossii. Dostoevskiy i sovremenniki: zhizn'v dokumentakh [To Be Born in Russia, Dostoevsky and His Contemporaries: Life in Documents]. Moscow, Kniga Publ., 1991. 607 p. (In Russ.)

3. Evnin F. I. Dostoevsky and Nekrasov. In: Russkaya literatura, 1971, no. 3, pp. 25-48. (In Russ.)

4. Zakharov V. N. About One Myth of Dostoevsky. In: Sever, 1985, no. 11, pp. 113-120. (In Russ.)

5. Letopis'zhizni i tvorchestva I. S. Turgeneva (1818-1858) [The Chronicle of Life and Work of I. S. Turgenev (1818-1858)]. St. Petersburg, Nauka Publ., 1995. 481 p. (In Russ.)

6. Letopis' zhizni i tvorchestva N. A. Nekrasova: $v 3$ tomakh [The Chronicle of Life and Work of N. A. Nekrasov: in 3 Vols]. St. Petersburg, Nauka Publ., 2006, vol. 1: 1821-1855. 581 p. (In Russ.)

7. Lukanina A. N. My Acquaintance with I. S. Turgenev (From Memories). In: I. S. Turgenev $v$ vospominaniyakh sovremennikov: $v 2$ tomakh [I. S. Turgenev in the Memoirs of His Contemporaries: in 2 Vols]. Moscow, 1969, vol. 2, pp. 221-234. (In Russ.)

8. Nasurdinova G. Ne zabyt' mne profil' bozhestvennyy... [I Can't Forget a Divine Side-View...]. Novgorod the Great, Pechatnyy dvor "Velikiy Novgorod" Publ., 2009. 119 p. (In Russ.)

9. Oksman Yu. Letopis' zhizni i tvorchestva V. G. Belinskogo [The Chronicle of Life and Works of V. G. Belinsky]. Moscow, Khudozestvennaya literatura Publ., 1958. 643 p. (In Russ.)

10. Panaev I. I. Some More Poems of a New Poet. In: Sovremennik, 1847, vol. 2, no. 4, department 4, pp. 154-159. (In Russ.)

11. Panaev I. I. The Notes of a New Poet About Life in St. Petersburg. In: Sovremennik, 1855, vol. 54, no. 12, pp. 235-268. (In Russ.)

12. Popov A. V. A. I. Herzen's Archival Heritage at Home and Abroad. In: Gertsenovskie chteniya VIII: materialy nauchnoy konferentsii [The Eighth Gertsen Readings: Proceedings of the Scientific Conference]. Kirov, 2002, pp. 6-12. (In Russ.)

13. Chulkov G. I. Zhizn' Dostoevskogo [The Life of Dostoevsky]. Moscow, the Gorky Institute of World Literature of the Russian Academy of Sciences Publ., 2015. 472 p. (Ser. "Source Studies of Literature of the 20th Century"; Issue 1). (In Russ.) 